\title{
Изучение противопаразитарных свойств препаратов Кенококс и Феностерил в отношении ооцист кокцидий кур
}

Симонова Е.А., младший научный сотрудник отдела паразитологии

Бирюков И.М., научный сотрудник отдела паразитологии

Всероссийский научно-исследовательский ветеринарной институт птицеводства (ВНИВИП) - филиал ФНЦ «ВНИТИП» РАН

Аннотация: Исследовали противопаразитарную активность препаратов Кенококс и Феностерил 6 отношении кокцидий кур. Главная задача противококцидийного средства заключается 6 воздействии как на спорулированные, так и неспорулированные ооцисты во внешней среде, не допуская их развития и дальнейцей репродукции $е$ организме птицы. Культуру кокиидий, содержаиую Eimeria acervulina и E. tenella, обрабатыВали исследуемыми препаратами, выдерживали экспозицию согласно инструкциям по их применению, и затем проводили микроскопическое исследование ооцист. Учитывали визуальную деформацию оболочки кокцидий и разрушения 6 их внутренней структуре. Прободили биологическую пробу на цыплятах-бройлерах 6 бозрасте 20 дней, заражая птицу в дозе 100 тыс. обработанных ооцист на голобу и определяя уровень репродукции ооцист кокцидий через 3 дня после заражения. Кенококс и Феностерил показали неплохую противопаразитарную активность, предотврацая проявление клинических признаков эймериоза у иьплят 6 течение 10 дней после заражения, однако полного отсутствия репродукиии кокцидий достигнуто не было; интенсэффективность изучаемых препаратов против ооцист составила 67,4 и $67,2 \%$ соответственно.

Ключебые слова: кокцидиоз, эймериоз, дезинфицирующие средства, ибплята-бройлеры, противопаразитарная активность, репродукция.

Введение. На сегодняшний день во многих странах мира разрабатываются дезинфицирующие средства, которые бы эффективно воздействовали на кокцидий кур, в том числе и на их ооцисты. Кокцидиоз до сих пор остается одной из самых распространенных болезней в птицеводческой отрасли, которая наносит ей серьезный экономический ущерб. Возбудителем болезни являются простейшие из рода Eimeria - одноклеточные паразиты, которые обладают строгой специфичностью, т.е. определенные виды эймерий могут паразитировать только у одного вида птицы. Кокцидии локализуются в различных отделах кишечника, в зависимости от вида паразита.
Эндогенная стадия жизненного цикла возбудителя протекает в эпителиальных клетках кишечника птицы, вызывая нарушение процессов пищеварения и усвоения питательных веществ, что приводит к снижению продуктивности, ухудшению качества мяса, задержке в росте и развитии, ослаблению защитных механизмов организма птицы с возникновением сопутствующих инфекционных и паразитарных болезней, а нередко и к гибели птицы [1].

На площадках птицеводческих хозяйств, как правило, циркулирует определенная полевая культура кокцидий. В условиях напольного содержания и высокой концентрации поголовья птицы происходит постоянная реинвазия и, как следствие, новые вспышки кокцидио$3 a$.

Мероприятия по профилактике эймериоза можно разделить на две группы. Одна группа имеет целью недопущение заражения птицы экзогенными стадиями кокцидий - ооцистами, находящимися во внешней среде; другая же направлена на борьбу с эндогенными стадиями развития паразита в организме птицы. Борьба с экзогенными стадиями развития кокцидий - это выполнение комплекса ветеринарно-санитарных мероприятий с применением специальных средств для дезинвазии внешней среды, предметов ухода и оборудования птичника. 
Важной особенностью кокцидий является их устойчивость $\mathrm{K}$ условиям внешней среды за счет двухконтурной липопротеиновой оболочки. Они легко переносят перепады температур, при этом большинство дезинфицирующих средств не оказывает губительного эффекта на ооцисты [2]. Подавлять споруляцию ооцист кокцидий могут такие вещества, как метилбромид, дисульфид углерода, аммиак и фенол, а также хлорсодержащие препараты, но далеко не все эти вещества могут быть относительно безопасно использованы в птицеводстве.

Целью наших исследований было изучение дезинвазирующих свойств препаратов Кенококс и Феностерил в отношении кокцидий кур.

Материал и методика исследований. Работу проводили в условиях лаборатории отдела паразитологии и инфекционного вивария ВНИВИП (Санкт-Петербург). Для данного исследования использовали смешанную полевую культуру кокцидий кур, в состав которой входили Eimeria acervulina и E. tenella.

Объектом исследования являлись препараты Феностерил и Кенококс. Противопаразитарное действие исследовали в концентрациях и экспозициях, указанных В инструкциях по применению. Проводили лизис-тест и биопробу на восприимчивой птице - цыплятах-бройлерах.

Лизис-тест проводили в условиях лаборатории отдела паразитологии ВНИВИП. Для данного опыта брали суспензию спорулирован- ных ооцист полевой культуры кокцидий. Суспензию разбавляли водой до получения концентрации 100 тыс. ооцист/мл, тщательно размешивали полученный раствор на магнитной мешалке в течение 30 мин.

Рабочие растворы препаратов Феностерил и Кенококс готовили в концентрациях, указанных В инструкциях по применению. В емкости одинакового объема поместили по 10 мл культуры кокцидий, содержащей по l млн. ооцист; затем добавили рабочие растворы исследуемых препараTOB.

В первую емкость добавили к 10 мл культуры кокцидий 90 мл 4\% раствора препарата Кенококс. Выдерживали экспозицию 2 4, согласно инструкции по применению.

Во вторую емкость добавили к 10 мл культуры кокцидий 90 мл 3\% рабочего раствора препарата феностерил. Выдерживали экспозицию 18 ч, согласно инструкции по применению.

В третью емкость к 10 мл культуры кокцидий добавили 90 мл воды. Эта проба являлась контрольной, без применения препаратов.

В каждой емкости получили равный итоговый объем растворов - по 100 мл. По истечении экспозиции проводили микроскопическое исследование ооцист кокцидий. Учитывали деформацию оболочки ооцист, а также изменения в их внутренней структуре после воздействия препарата.

После проведения микроскопии проводили отмывание обра- ботанных препаратом ооцист отдельно в каждой пробе путем трехкратного центрифугирования с водой в течение 5 мин при 3000 об./мин. Надосадочную жидкость осторожно сливали. Затем добавляли к полученному осадку воду, чтобы разведение в 1 мл составило 100 тыс. ооцист для каждой пробы.

Биологическую пробу проводили на цыплятах-бройлерах, доставленных из хозяйства, благополучного по инфекционным и инвазионным заболеваниям. Птица доращивалась до 20-дневного возраста в условиях, исключающих спонтанный кокцидиоз. Во время опыта условия содержания и кормления опытной птицы были одинаковыми. Было сформировано 4 группы цыплят по 8 голов в каждой. 1 группа - незараженная контрольная (чистая); 2 группа - контрольная зараженная; 3 группа - зараженная ооцистами, обработанными 4\%препаратом Кенококс; 4 группа - зараженная ооцистами, обработанными 3\% препаратом Феностерил.

Заражение цыплят групп 2-4 проводили в 20-дневном возрасте в дозе по 1 мл на голову (по 100 тыс. ооцист). Учитывали клинические признаки кокцидиоза: взъерошенность перьевого покрова, угнетение, снижение аппетита, наличие кровянистых сгустков в помете. Наблюдение за птицей вели в течение 10 дней.

Главным показателем противопаразитарной активности препарата в данном исследовании являлся уровень репродукции ооцист кокцидий в помете за 3 суток патентного периода. Собирали в разные 
емкости одинакового объема весь помет, полученный от птицы, за 3 суток с момента начала выхода ооцист во внешнюю среду. Тщательно его размешивали, доводя смесь до абсолютно гомогенной массы. Добавляли воду к каждой пробе помета, чтобы объем был 11 л. Такое разведение и тщательное длительное перемешивание способствуют максимально равномерному распределению ооцист в толще смеси.

Из каждой емкости было взято во время размешивания по 50 мл смеси. Тщательно размешивали эту среднюю пробу на магнитной мешалке в течение 20-30 мин. Проводили подсчет количества ооцист в каждой из трех проб в камере Горяева (подсчет в 4 полях камеры для каждой пробы).

Проводили подсчет общего количества выделенных ооцист для каждой опытной группы, затем подсчитывали репродукцию кокцидий на 1 голову, что и является самым важным показателем репродукции.

Результаты исследования и их обсуждение. При микроскопическом исследовании ооцист, обработанных препаратом Кенококс в 4\% концентрации и с экспозицией 2 ч, была заметна несущественная деформация оболочки. Внутренняя структура большинства ооцист сохранилась неизменной. Наблюдалось небольшое количество ооцист, где спорозоиты утратили свою форму. У некоторых ооцист оболочка была порвана, произошел выход спороцист.

После обработки культуры кокцидий препаратом Феностерил в концентрации 3\% и при экспозиции 18 ч наблюдали разрушение многих ооцист кокцидий. Спорулированных, способных к заражению ооцист почти не было. Оболочка была деформирована, у некоторых ооцист порвана. Внутренняя структура не имела четких границ.

Микроскопия контрольной (не обработанной препаратами) пробы изменений в структуре ооцист не выявила.

В 1 группе (чистый контроль) после заражения цыплят клинических признаков заболевания не наблюдалось; во 2 группе (контрольная зараженная) имелись явные признаки эймериоза (снижение аппетита, взъерошенность перьевого покрова, угнетение, кровянистые сгустки в помете). У птиц в опытных группах с применением препаратов Феностерил и Кенококс клинических признаков кокцидиоза практически не наблюдалось (лишь небольшое количество примеси крови в помете и снижение аппетита). За время опыта ни один цыпленок не пал.

Главным показателем действия противопаразитарного препарата является уровень репродукции кокцидий, т.е. количество ооцист, выделенных во внешнюю среду.

За 3 суток патентного периода у опытной группы с применением 4\% Кенококса одним цыпленком было выделено в среднем порядка 181,8 млн. ооцист. В группе с применением препарата Феностерил среднее количество ооцист на одну голову составило порядка 184,8 млн. В контрольной зараженной группе одним цыпленком за 3 дня патентного периода было выделено порядка 563,7 млн. ооцист. В чистой контрольной группе ооцист в помете не наблюдалось.

Для опытных групп птицы рассчитывали репродуктивный индекс (РИ) по формуле: $P И=B / D$, где В - количество ооцист, выделенных одним цыпленком за патентный период; D - доза заражения (для данного опыта она составляла 100000 ооцист на голову).

РИ для 2 группы (зараженного контроля):

PИ2 $=563693625 / 100000=$ 5637.

РИ для 3 группы (с применением препарата Кенококс):

PИ3 $=181787375 / 100000=$ 1818.

РИ для 4 группы (с применением препарата Феностерил):

PИ4 $=184842625 / 100000=$ 1848.

Отношение РИ зараженного контроля и группы с применением препарата Кенококс составило: 5637 / $1818=3,1$; зараженного контроля и группы с применением препарата Феностерил: $5637 / 1848=3,0$.

Далее рассчитывали значение интенсэффективности препарата (ИЭ) - процента выделившихся ооцист по отношению к их количеству в исходном состоянии до применения препарата. Расчет производился по формуле:

ИЭ $=\left(\left(\mathrm{KO}_{\mathrm{K}}-\mathrm{KO}_{\mathrm{A}}\right) / \mathrm{KOK}\right)^{*} 100$,

где ИЭ - интенсэффективность препарата, \%; КОк - количество ооцист у цыплят зараженной контрольной группы; КОд - количество ооцист у цыплят, получавших обработанные дезинфектантом ооцисты. 
Для группы с препаратом КеноKOKC:

ИЭ $=((563693625-181787375)$ $(563693625)^{*} 100=67,4 \%$;

для группы с препаратом Феностерил:

ИЭ $=((563693625-184842625)$ / 563693625$)^{*} 100=67,2 \%$.

Заключение. Результаты исследования показали, что оба препарата в протестированных концентрациях не оказали на ооцисты кокцидий значимого противопаразитарного воздействия.

Препарат Кенококс показал сниженную в 3,1 раза по отношению $\mathrm{k}$ контрольной группе репродукцию ооцист кокцидий, что говорит о неплохой противопаразитарной активности. Дезинвазия с применением этого препарата достаточно эффективна в птицеводческом хозяйстве.

При микроскопии ооцист, обработанных препаратом Феностерил, была отмечена существенная деформация оболочки и внутренней структуры кокцидий. Длительная экспозиция с этим препаратом дала дополнительный положительный эффект. Репродукция эймерий была ниже контрольной в 3,0 раза. Можно сделать вывод, что применение этого препарата окажет благоприятный эффект при дезинвазии птицеводческих помещений.

По интенсэффективности препаратов были получены следующие значения: для Кенококса 67,4\%; Феностерила-67,2\%.

Стопроцентной гибели ооцист в формате проведенного эксперимента достигнуто не было. Разница в репродукции ооцист между контрольной зараженной и опытными группами свидетельствует о том, что часть ооцист погибла под влиянием препаратов, но, тем не менее, основная часть кокцидий жизнеспособность не потеряла, о чем говорит достаточный уровень их репродукции. Это дает основание утверждать, что данные препараты не обладают высокой противопаразитарной эффективносTbю.

Исследование Qbиолнено 6 coomGemcmGuи c mематикой НИР ВНИВИП по Госзаданию № 0599-2019-0023.

Литература

1. Кириллов А.И. Кокцидиозы птиц. M., 2008. - C. 7-12.

2. Хейсин Е.М. Жизненные циклы кокцидий домашних животных. - Л., 1967. -C. 58.

\section{Для контакта с авторами:}

Симонова Екатерина Александровна

E-mail: vetsaneco.vnivip@yandex_ru

Бирюков Илья Михайлович

E-mail: i_biryukov88@mail.ru

\section{The Efficiency of the Elimination of Coccidial Oocysts in Chicken by Preparations Kenocox ${ }^{\bullet}$ and Phenosterile}

Simonova E.A., Biryukov I.M.

Federal Scientific Center "All-Russian Research and Technological Institute of Poultry" of Russian Academy of Sciences

Summary: Anticoccidial effects of preparations Kenocox (Belgium) and Phenosteri/ (France) were studied on the coccidial oocysts. An effective coccidiostatic should effectively eliminate both sporulated and non-sporulated coccidial forms to prevent their further development and reproduction in poultry. The cultures containing Eimeria acervulina and E. tenella were treated with the preparations in doses and expositions recommended by the producers. Microscopic investigation of treated oocysts was performed to assess visual deformations of the oocystic cell walls and degree of internal destruction. Broiler chicks at 20 days of age were inoculated by treated oocysts in the dose 100,000 per bird; the intensity of coccidial reproduction was determined in the chicks in 3 days after the inoculation. Kenocox ${ }^{\oplus}$ and Phenosteril ${ }^{\circ}$ prevented the observable symptoms of the eimeriosis in inoculated chicks during 10 days of the observation though coccidial reproduction was not completely depressed; the coefficients of elimination efficiency for the oocysts were 67.4 and $67.2 \%$ respective to the preparations studied.

Key words: coccidiosis, eimeriosis, disinfectants, broiler chicks, elimination efficiency, reproduction. 